\title{
Nurse Workloads Affecting Negative on Patient Safety in Hospital (Case Study at X Hospital)
}

\author{
Mersy Delty Kainama ${ }^{1}$, Ratna Indrawati ${ }^{1}$, Rina Mutiara ${ }^{1}$ \\ ${ }^{1}$ Master of Hospital Administration, Esa Unggul University, Jakarta. Jl. Arjuna Utara No.9, RT.1/RW.2, Duri Kepa Daerah \\ Khusus Ibukota Jakarta 11510, Indonesia
}

DATA OF ARTICLE:

Received: 19 Mar 2020

Reviewed: 30 Apr 2020

Revised: 20 May 2020

Accepted: 19 Jun 2020

\section{*CORRESPONDENCE:}

mersydelty@yahoo.co.id

DOI:

10.18196/mm.200244

TYPE OF ARTICLE:

Research

\begin{abstract}
The workload is pressure or difficulty adjusting due to psychological and physical demands on a person. For nurses, this will affect patient safety. The system in the hospital must make patient care safe, that is, it can prevent injury due to incorrect action. The system includes risk recognition, identification, and management of patient risks, incident reporting, and analysis. The results of the evaluation at X Hospital showed that compliance with the risk of injury to patients due to falls in the inpatient department was $99 \%$, compliance with handwashing was $65.3 \%$, and patient and family satisfaction was $70.9 \%$. The purpose of this study was to analyze the effect of nurses' workload on the implementation of patient safety at X Hospital where the service quality variable was intervening. This research is analytic observational with a statistical test of path analysis multiple regression. The number of research subjects was 74 nurses who worked at $\mathrm{X}$ Hospital. Data were obtained using a questionnaire. The results indicate that there is a significant effect of nurses' workload on patient safety, but service quality cannot be an intervening variable on both variables. The most dominant variable for patient safety is the workload of nurses.
\end{abstract}

Keywords: Nurse Workload; Patient Safety; Intervening Variable.

\begin{abstract}
Abstrak: Beban kerja adalah tekanan atau kesulitan menyesuaikan diri karena tuntutan psikologi dan fisik terhadap seseorang. Pada perawat, hal ini akan berpengaruh pada keselamatan pasien. Sistem di rumah sakit harus membuat asuhan pasien aman, yaitu dapat mencegah cedera akibat kesalahan suatu tindakan. Sistem tersebut meliputi pengenalan risiko, identifikasi dan pengelolaan risiko pasien, pelaporan dan analisis insiden. Hasil evaluasi di RS X menunjukkan bahwa kepatuhan pencegahan risiko cedera pasien karena jatuh di departemen rawat inap sebesar 99\%, kepatuhan mencuci tangan sebesar 65.3\%, dan kepuasan pasien dan keluarganya sebesar 70.9\%. Tujuan penelitian ini untuk menganalisis pengaruh beban kerja perawat terhadap penerapan keselamatan pasien di RS X dimana variabel mutu pelayanan adalah sebagai variabel intervening. Penelitian ini bersifat observasional analitik dengan uji statistik path analysis regresi berganda. Jumlah subyek penelitian adalah 74 perawat yang bekerja di RS X. Data diperoleh dengan menggunakan kuesioner. Hasil menunjukkan adanya pengaruh yang signifikan beban kerja perawat terhadap keselamatan pasien namun mutu pelayanan tidak bisa sebagai variabel intervening terhadap kedua variabel. Variabel paling dominan terhadap keselamatan pasien adalah beban kerja perawat.
\end{abstract}

Kata Kunci: Beban Kerja Perawat; Keselamatan Pasien; Variabel Intervening.

\section{INTRODUCTION}

More than 100 million people need surgical treatment every year for different medical reasons. Problems associated with surgical safety in developed countries are avoiding causes that result in death or disability, the economic benefits of efforts to increase patient safety are numerous. There is one in a million opportunities someone experiences an accident on an airplane. In comparison, one in 300 chances of a patient get injured during the health care process. The patient's 
experience and their health are at the heart of the patient safety movement. Patient safety incidents, in the future, referred to as incidents, are any accidental events and conditions that result in or have the potential to cause preventable injury to patients, consisting of unexpected events, near misses, non-injuries, and potential injuries.1

WHO and various institutions establish the "World Alliance for Patient Safety" to lift patient safety Goals "First not harm" and reducing morbidity, injuries, and deaths suffered by patients.2 In the Ministry of Health (2010),3 the factors contributing to the occurrence of the adverse events and near-miss are external hospital factors, organizational and management factors, work environment, teamwork, officers, workload, or tasks, patients, and communication factor.

Patient safety is an absence of error or injuryfree. Patient safety is a system where the hospital makes patient care safer, prevents injury caused by mistakes due to carrying out an action or not taking the action that should have been taken. The system includes risk recognition, identification, and management of matters related to patient risk, reporting, and analysis of incidents, the ability to learn from experiences, follow-up, and implementing solutions to minimize risk. Includes risk assessment, identification, and management of matters relating to patient risk, reporting, and analysis of incidents, the ability to learn from experiences and their follow-up, implementation of solutions to minimize risk. 4

The patient safety indicator is a measure used to determine the level of patient safety during hospitalization. This indicator can be used in conjunction with inpatient data that has been allowed to leave the hospital. Indicators of patient safety are useful to illustrate the magnitude of problems experienced by patients during hospitalization, especially those related to various medical actions that have the potential to pose risks on the patient's side. By basing on these patient safety indicators, the hospital can establish efforts to prevent the emergence of unexpected clinical outcomes in patients. 5

The workload arises from the interaction between the demands of tasks, the work environment used as a workplace, the skills, behavior, and perceptions of workers. Quality of service is a must that must be done by the company to be able to survive and still get the trust of customers. Consumption patterns and customer lifestyles require companies to be able to provide quality services. The success of the company in providing quality services can be determined by the service quality approach. 6
Regarding patient safety at X Hospital, based on the results of the 2018 evaluation, the compliance with the risk of injury due to patients falling on the inpatient department reached $99 \%$ of the $100 \%$ standard, where only $1 \%$ is still a problem in preventing fall risk. But for compliance in washing hands is still below the average of $65.3 \%$ with a standard of $>85 \%$. This condition significantly affects the patient's risk of transmission. The factors of non-compliance nurses in washing hands before coming to contact with patients need to be studied. Patient and family satisfaction were $70.9 \%$ (standard $>80 \%$ ). The factors that the patient feels dissatisfied with must be reviewed and reviewed.

\section{MATERIALS AND METHOD}

This is an analytic observational research. The number of subjects were 74 nurses by total sampling method. Data obtained using a questionnaire. The results of the study were performed on statistical tests with computers. The type of test performed is Multiple Regression and Path Analysis.

There are three hypotheses in this research, $\mathrm{H} 1$ : There is an influence of nurse workload on the application of patient safety with the quality of service as an intervening variable. $\mathrm{H} 2$ : There is an influence of the nurse's workload on the application of patient safety. H3: There is an influence of workload on the quality of services provided by nurses. $\mathrm{H}_{4}$ : There is an influence on the quality of service with the application of patient safety.

\section{RESULT}

This research involved 74 participants who the characteristics presented in Table 1. Table 1 shows that the majority of respondents aged 21-30 years (79.7\%). The characteristics of respondents according to education most of the respondents have a $D_{3}$ education level with a total of 65 people (87.8\%), according to employee status that is a contract employee with a total of 39 people (52.7\%) and the working period of the respondents, i.e., tenure $<3$ years with a total of 31 people (41.9\%).

Table 2 shows the results of the analysis to determine the factors that affect patient safety. In Table 2, it could be seen that interactions between the variables are all significant $(p<0.05)$ with a strong correlation coefficient $\left(R^{2}>0.6\right)$, but the variable quality of service to patient safety is not significant. Based on the correlation calculation, the path coefficient is found as shown in Figure 1.

Table 1. Characteristics of participant 


\begin{tabular}{|c|c|c|c|}
\hline No & $\begin{array}{c}\text { Characteristics } \\
\text { Factor }\end{array}$ & Total & Percentage \% \\
\hline \multirow[t]{7}{*}{1} & Age (year old) & & \\
\hline & $21-25$ & 30 & 40.5 \\
\hline & $26-30$ & 29 & 39.2 \\
\hline & $31-35$ & 6 & 8.1 \\
\hline & $36-40$ & 6 & 8.1 \\
\hline & $40-50$ & 3 & 4.1 \\
\hline & Total & 74 & 100.0 \\
\hline \multirow[t]{5}{*}{2} & Education & Total & Percentage \% \\
\hline & D3 & 65 & 87.8 \\
\hline & S1 & 2 & 2.7 \\
\hline & Profesion (Nurse) & 7 & 9.5 \\
\hline & Total & 74 & 100.0 \\
\hline \multirow[t]{5}{*}{3} & Employee Status & Total & Percentage \% \\
\hline & Permanent & 29 & 39.2 \\
\hline & Contract & 39 & 52.7 \\
\hline & Other & 6 & 8.1 \\
\hline & Total & 74 & 100.0 \\
\hline \multirow[t]{7}{*}{4} & Years of Service & Total & Percentage \% \\
\hline & $<3$ year & 31 & 41.9 \\
\hline & Three year & 15 & 20.3 \\
\hline & Five year & 7 & $9 \cdot 5$ \\
\hline & $>5$ year & 12 & 16.2 \\
\hline & Ten year & 9 & 12.2 \\
\hline & Total & 74 & 100.0 \\
\hline
\end{tabular}

Table 2. Analysis About Workload, Service Quality and Patient Safety

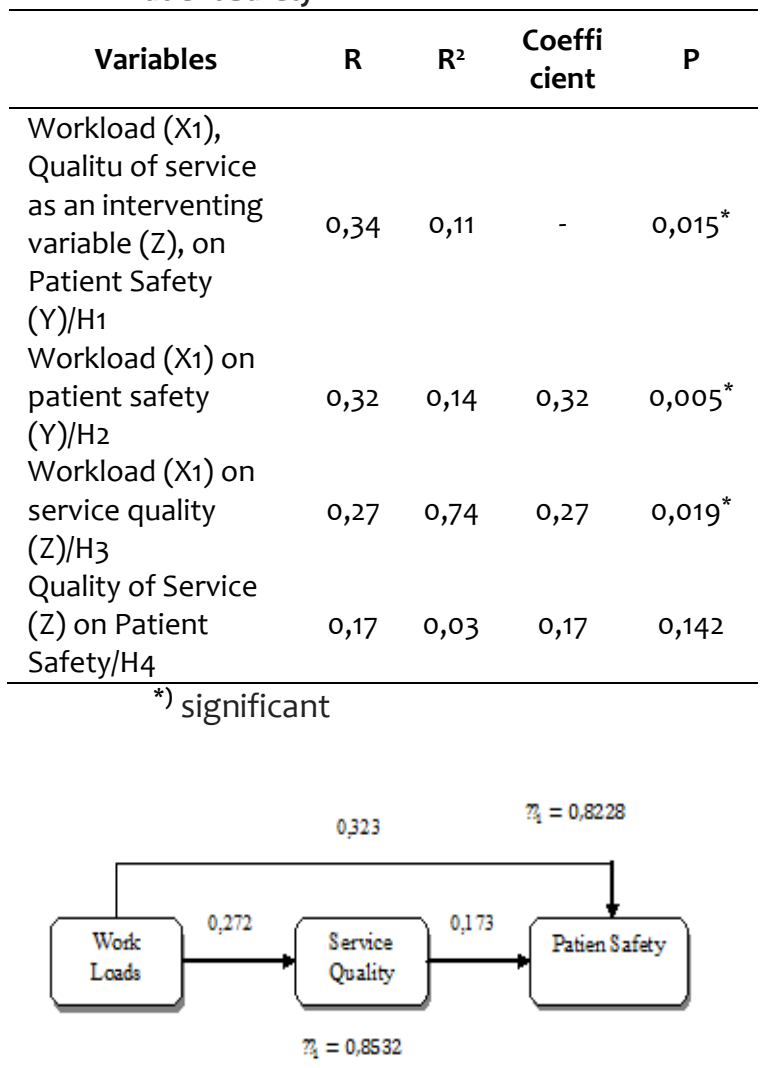

Figure 1. Variable Path Coefficient
Effect of nurse workload $\left(X_{1}\right)$ on the application of patient safety $(Y)$ with service quality $(Z)$ as an intervening variable

Based on data has been processed, it is known that the significant value of the variable workload and quality of service to patient safety is 0.015 . These results give the meaning that workload and service quality affect patient safety. The direct effect of the workload variable on patient safety is 0.323 . While the indirect effect of workload and service quality on patient safety is $0.323 \times 0.173=$ 0.040 . Thus, the total effect of patient safety is $0.323+0.040=0.363$ The direct effect of service quality on patient safety is 0.173 while the indirect effect is $0.173 \times 0.272=0.047$. Thus the total effect given by the service quality variable on patient safety is $0.363+0.047=0,41$. Based on the results of the three-box calculations also indicate that the workload is in the medium category, patient safety is in the category performed, and the quality of service is in a good category. The three-box descriptive results show that some of the most dominant statements have the highest and lowest values. Based on the results above, this description shows the influence of workload and service quality on patient safety. Still, the workload and service quality in this study shows a negative effect. Because the results of the three boxes show that the workload of nurses is still in the moderate category, the safety of patients is still in the category, and the service quality is still in the good category.

\section{Effect of nurse workload (X1) on patient safety $(\mathrm{Y})$}

Based on the data that has been processed with the regression model shown in Table 2, it could be seen that the significant value of the workload variable $p=0.005$ is smaller than 0.05 . Value of e_1 $V(1-0.323)=0.8228$. The contribution of workload to patient safety is 0.323 . Based on the results of three box calculations also indicate that the workload is in the medium category, and patient safety is in the category carried out. The three-box descriptive results show that some of the most dominant statements have the highest and lowest values. In the workload, the highest index is on the target indicator that must be achieved item. "My working hours in shifts are too burdensome. (BK2) and my type of work is relatively low, which makes me uncomfortable. (BK21) "that is equal to 49.6 and included in the medium category. The lowest index is on the condition indicator item. "In carrying out nursing services, I work well with other friends (BK13), which is 25.2 and belongs to the low 
category and patient safety. Based on the results above, the influence of workload on patient safety in the hospital has a negative effect because the results obtained from the three-boxes of the two variables are still in the appropriate category. The nurse's workload is still in the moderate category, so carrying outpatient safety is still done well. Nurses continue to carry out patient safety standards according to the standard operating procedure.

Effect of workload (X1) on service quality (Z) as an intervening variable

Based on data that has been processed with the regression model shown in table 4.10 , it could be seen that the significant value of the workload variable $p=0.019$ is smaller than 0.05 . But the results of $R_{2}$ show an $R_{2}$ value of 0.74 . Thus, the workload on quality has an effect of $74 \%$; other factors influence the remaining $26 \%$. The value of e_1 $=V(1-0.272)=0.8532$. The contribution of workload to service quality is 0.272 .

Based on the results of the three-box calculation also shows that the workload is in the medium category, and the service quality is in an excellent category. The three-box descriptive results show that some of the most dominant statements have the highest and lowest values.

\section{The effect of service quality on patient safety}

Based on the data that has been processed with the regression model shown in Table 2, it could be seen that the significant value of the variable quality of service to patient safety is $p=0.142$, more significant than 0.05 . Thus the quality of service does not affect patient safety.

Path Analysis uses regression analysis to estimate the causality relationship between variables (causal models or causation. A direct connection occurs if one variable affects the other variables without a third variable that mediates (intervening) the relationship between the two variables. An indirect relationship is if there is a third variable which mediates the relationship between these two variables. The intervening test is calculated by seeing the valid value of the estimation parameter where the indirect effect is greater than the indirect effect $(P T L>P L)$

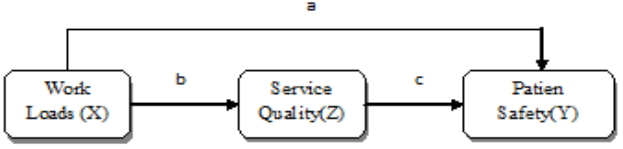

Picture 2. Intervening Test Path Analysis Where

$\mathrm{a}=0.274$

$\mathrm{b}=0.272$

$c=0.173$

intervening test: $\mathrm{PTL}>\mathrm{PL}$

$0,272 \times 0,173=0,47056$

Based on the calculation (1), it can be concluded that the quality of service cannot be intervening or has a direct relationship with the workload and patient safety at the hospital.

\section{DISCUSSION}

Effect of workload on patient safety with service quality as an intervening variable

Based on this study found the contribution of workload to patient safety with intervening service quality amounted to 0.112 with a value of $p=0.015$. This condition shows a significant positive effect between workload on the application of patient safety and service quality as an intervening variable.

The hospital nurses who work have different backgrounds ranging from years of service, age, education level, and employment status. The average employee who does is a contract employee; therefore, nurses are not thoroughly familiar with their work environment.

This study shows that the variable workload and service quality can affect patient safety. This result is in line with the research conducted by Martyastuti (2016),7 but it is different from the research conducted by Haryanto et al. (2018). 8 Haryanto (2018) states that workload does not affect patient safety, but is more influenced by patient safety culture in nursing care for patients at risk of falling. This shows that the effect of workload on patient safety is still inconsistent between one study and another. This is probably due to the complexity of the factors that affect patient safety.

The description outlined in the three-box model shows that the workload is in the medium category, with $35.3 \%$. Workload arises from the interaction between the demands of tasks. In this work environment, it is used as a workplace, skills, behavior, and perceptions of workers.

According to Kohn et al. (2000), ${ }^{4}$ Patient Safety was the absence of error or freedom from injury due to accidents. Patient safety is a system where the hospital makes patient care safer, prevents damage caused by mistakes due to carrying out an action or not taking the action that should have been taken. The system includes risk recognition, identification, and management of 
matters related to patient risk, reporting, and analysis of incidents, the ability to learn from experiences, follow-up, and implementing solutions to minimize risk. Includes risk assessment, identification, and management of matters related to patient risk, reporting, and analysis of experiences, the ability to learn from incidents and their follow-up, implementing solutions to minimize risks.

According to Parasuraman et al., ${ }^{6}$ quality of service is a necessity that must be done by the company to be able to survive and continue to get customer trust. Consumption patterns and customer lifestyles require companies to be able to provide quality services. The service quality approach can determine the success of the company in providing quality service. In this case, the theory of understanding each variable explains the characteristics of the variable itself, its relation in this study, that every nurse has different working conditions, work environment, and level of work. So that it can provide services to patients who need assistance, the link with patient safety is that patients will very much expect to get excellent service and get comfort and safety when getting medical treatment.

\section{Effect of workload on patient safety}

Based on this study found the contribution of workload to patient safety is 0.323 with a value of $p=0.005$. This condition shows that there is a positive influence between the two variables. This research is in line with research conducted by Retnaningsih and Fatmawati (2016).9 The results showed that the workload of nurses in the inpatient room was high (58.7\%), whereas most patient safety implementations were poor (60.6\%). Chi-Square analysis results obtained $X_{2}=6,81$ ( $\left.p=0,0009\right)$. There is a significant relationship between the workload of nurses and the implementation of patient safety in the inpatient room of the Tugurejo Regional Hospital Semarang. Work, skills, behavior, and perception of workers.

According to Kohn et al. (2000), 4 Patient Safety was the absence of error or freedom from injury due to accidents. Patient safety is a system where the hospital makes patient care safer, prevents injury caused by mistakes due to carrying out an action or not taking the action that should have been taken. The system includes risk recognition, identification, and management of matters related to patient risk, reporting, and analysis of incidents, the ability to learn from incidents, follow-up, and implementing solutions to minimize risk. Includes risk assessment, identification, and management of matters related to patient risk, reporting, and analysis of incidents, the ability to learn from incidents and their followup, implementing solutions to minimize risks. Based on the results of research and theories raised by severe experts about these two variables, and the relation of this study to workload very influential on patient safety. Research shows nurse's workload is in the medium category with an average value of 35.3 or $35.3 \%$, and implementation of patient safety is included in the category of yes with an average value of 34 or $34 \%$. The lowest index is on the indicator condition item "In implementing nursing service cooperates well with other friends (BK13), 25.2 and belongs to the low category and patient safety. The research shows that although the workload of nurses is in the category. In contrast, nurses continue to live the patient safety standards by applicable SOP in hospitals. Thus the workload negatively affects patient safety

\section{Effect of workload on service quality}

Based on the research found the contribution of workload to service quality is 0.272 , with the value of $p=0.019$. This study is in line with Werdani's research,10 which shows the results of the Statistical Test using ordinal regression $\mathrm{P}<0.05$. Results: There is a significant influence between the mental workload of nurses on the level of patient satisfaction that is $p<0.001$. Workload arises from the interaction between the demands of tasks, the work environment where it is used as a workplace, skills, behavior, and perceptions of workers. There are two types of workloads, namely physical workloads and mental workloads.

According to Rifqiansyah (2017), ${ }^{11}$ the perception of a work mismatch and work environment among employees is an indication of excessive mental workload. Meanwhile, physical loads tend to lead to loads related to their physiological conditions. An excessive job description due to the limited number of employees is an indication of an excessive physical workload.

According to Shah et al. (2011), ${ }^{12}$ workload is a source of stress on employees. Job stress will affect job security, ${ }^{13}$ but not necessarily affect service quality. ${ }^{14}$ Quality of service is the expected level of excellence and control over the status of excellence to meet the customer's wishes. According to Parasuraman et al. (2010), ${ }^{6}$ quality of service is a necessity that must be done by the company to be able to survive and continue to get customer trust.

Consumption patterns and customer lifestyles require companies to be able to provide 
quality services. The service quality approach can determine the success of the company in giving quality service. Based on the results of research and theories raised by severe experts about the two variables, the workload is significant to be considered in carrying out duties as nurses who provide services to patients. If the workload is not high, the quality of the services offered will also be excellent.

Based on the results of the three-box calculation also shows that the workload is in the medium category, and the service quality is in a suitable variety. The three-box descriptive results show that some of the most dominant statements have the highest and lowest values. Although nurses have a workload, nurses can run acceptable service standards so that the quality of service created is excellent and following patient expectations. Based on the results of the study and the results of the three-box workload harms service quality.

\section{The effect of service quality on patient safety}

Based on the research found the contribution of service quality to patient safety is 0.173 with the value of $p=0.142$. The quality of service does not have a significant influence on patient safety. According to Parasuraman et al, (2010), ${ }^{6}$ Quality of service is a necessity that must be done by the company to be able to survive and continue to get customer trust. Consumption patterns and customer lifestyles require companies to be able to provide quality services. The service quality approach can determine the success of the company in providing quality services. According to Kohn et al. (2000), ${ }^{4}$ patient safety was the absence of error or freedom from injury due to accidents. Patient safety is a system where the hospital makes patient care safer, prevents damage caused by mistakes due to carrying out an action or not taking the action that should have been taken. The system includes risk recognition, identification, and management of matters related to patient risk, reporting, and analysis of incidents, the ability to learn from experiences, follow-up, and implementing solutions to minimize risk. Includes risk assessment, identification, and management of matters related to patient risk, reporting, and analysis of incidents, the ability to learn from experiences and their follow-up, implementing solutions to minimize risks.

This study is not in line with the research conducted by Zakaria (2017), ${ }^{15}$ showing a correlation coefficient ( $r$ ) of 0.904. A positive and robust relationship between variable service quality and patient safety goals with patient satisfaction.
Based on calculations using three boxes also found that the quality of service in hospitals is very good with a percentage of $24.4 \%$ of patient safety contained in yes category, with a ratio of $34 \%$. Thus, the quality of service does not affect patient safety at the hospital. Workload and service quality negatively affect patient safety. Service quality cannot be an intervening variable. Workload harms service quality and negatively affects patient safety.

\section{Managerial Implications}

This study has implications for hospital managerial as follows: 1). The nurses accept a fee when running a double job; 2 ). Work stress needs to be reduced, and the morale of nurses needs to be increased so that they can carry out work and services to patients; 3 ). The career development of each nurse is carried out with a good work cycle; 4). Patient safety standards are maintained through regular training; 5). Monitoring and evaluation of the implementation of patient safety are carried out, among others, regarding the behavior of nurses' handwashing and the workload of nurses.

\section{CONCLUSION}

There are 3 points of research results: 1 ). The effect of workload on the quality of patient safety services cannot be used as an intervening variable. Moderate category workload with excellent service quality affects patient safety; 2). The moderate workload category affects patient safety, even though the application of patient safety has been carried out according to the SOP; 3). Workload affects service quality, but service quality does not affect patient safety.

\section{REFERENCES}

1. WHO. Patient safety: the rising star of clinical care. url https://www.who.int/dg/speeches/2012/patient safety_20121022/en/

2. WHO: World Alliance for Patient Safety, Forward Programme, url https://www.who.int/patientsafety/worldallianc e/en/

3. Permenkes RI No.1691/Menkes/VIII/2011 about Hospital Patient Safety. Retrieved 11 23, 2015, from http://202.70.136.86/bprs/uploads/pdff, 2011.

4. Kohn LT, Corrigan JM. \& Donaldson MS. To err is human: Building a safer health system. Washington DC., National academy press. 2000. DOI: $10.17226 / 9728$ 
5. Mulyati L. dan Asep S. Pengembangan Budaya Patient Safety dalam Praktik Keperawatan. 2011. http://www.stikku.ac.id/wpcontent/uploads/2011 102/PENGEMBANGAN-BUDAYA-PATIENTSAFETY.pdf

6. Parasuraman A, Zeithaml VA, Berry LL. A Conceptual Model of Service Quality and Its Implication for Future Research. Journal of Marketing, 2010: 49: 41 - 50

7. Martyastuti NE. Hubungan Antara Faktor Individu dan Persepsi Organisasi dengan Kinerja Perawat Pelaksana dalam Penerakan Keselamatan Pasien di Ruang Rawat Inap RSUD Bendan Kota Pekalongan. Tesis. Program Studi Magister Keperawatan Fakultas Kedokteran Universitas Diponegoro. Semarang. 2010.

8. Haryanto J, Kodyat AG, dan Rahayu S. Pengaruh Beban Kerja dan Budaya Keselamatan Pasien terhadap Asuhan Keperawatan Risiko Jatuh di Ruang Rawat Inap Rumah Sakit X Tahun 2017. Jurnal Manajemen dan Administrasi Rumah Sakit. Oktober 2018: 2 (2): 1-17

9. Retnaningsih D, Fatmawati D. Beban Kerja Perawat terhadap Implementasi Patient Safety di Ruang Rawat Inap. Jurnal Keperawatan Soedirman (The Soedirman Journal of Nursing); Maret 2016: 11 (1): 44-52

10. Werdani YDW. The effect of the mental workload of nurses on the level of patient satisfaction in the inpatient room of a private hospital at Surabaya. Proceedings of the 8th International Nursing Conference on Education, Practice and Research Development in Nursing (INC 2017). https://doi.org/10.2991/inc-17.2017.9

11. Rizqiansyah MZA. Hubungan antara Beban Kerja Fisik dan Beban Kerja Mental Berbasis Ergonomi Terhadap Tingkat Kejenuhan Kerja pada Karyawan PT Jasa Marga (Persero) Tbk Cabang Surabaya Gempol. Jurnal Sains Psikologi. Maret 2017:6(1): 37-42

12. Shah SSH, Jaffari AR, Aziz J, Ejaz W, Ul-Haq I, \& Raza SN. Workload and Performance of Employees. IJCRB. 2011: 3 (5): 256-267.

13. Tarwanto, IB. Analisis Kompensasi, Tingkat Stres, dan Keamanan Kerja Terhadap Kepuasan Kerja. Jurnal Ecodunamika:2019:2(2):1-7

14. Kurnia, R. Pengaruh stres kerja terhadap kualitas layanan pada karyawan Bangi Kopitiam, Surabaya. Tesis. Universitas Katolik Widya Mandala Surabaya, 2016.

15. Zakaria FM. Pengaruh kualitas pelayanan dan sasaran dan sasaran keselamatan pasien terhadap kepuasan pasien di RS Prima Husada Malang. JIMMU Agustus 2017: II (2). 98-107 